\title{
Validation of the Pregnancy Physical Activity Questionnaire (PPAQ) Walidacja kwestionariusza Pregnancy Physical Activity Questionnaire (PPAQ)
}

\author{
Edyta Suliga ${ }^{1}$, Kamila Sobaś², Grzegorz Król $^{3}$ \\ ${ }^{1}$ Department of the Prevention of Alimentary Tract Diseases, Institute of Nursing and Obstetrics, Faculty of Medicine and Health \\ Science, Jan Kochanowski University, Kielce, Poland \\ Head of the Department: Prof. Grażyna Rydzewska MD, PhD \\ ${ }^{2}$ Department of the Prevention of Alimentary Tract Diseases, Institute of Nursing and Obstetrics, Faculty of Medicine and Health \\ Science, Jan Kochanowski University, Kielce, Poland \\ Head of the Department: Prof. Grażyna Rydzewska MD, PhD \\ ${ }^{3}$ Department of Physiology, Institute of Medical Science, Faculty of Medicine and Health Science, Jan Kochanowski University, \\ Kielce, Poland \\ Head of the Department: Prof. Robert Bucki MD, PhD
}

Key words: physical activity questionnaire, pregnant women, validation, reproducibility.

Słowa kluczowe: kwestionariusz aktywności fizycznej, kobiety w ciąży, walidacja, powtarzalność.

\begin{abstract}
Introduction: The results of many studies confirm the positive effect of physical activity during pregnancy on the health of both mother and child. Due to this, it is important to use standardised methods of its assessment. In 2004, Chasan-Taber et al. developed the Pregnancy Physical Activity Questionnaire (PPAQ), taking into account household/caregiving activities, occupational activities, sports/exercise activities, transportation activities, and inactivity.

Aim of the research: The validation of the Pregnancy Physical Activity Questionnaire (PPAQ) by determination of its reproducibility.

Material and methods: The questionnaire was validated from June 2014 to February 2015 among 164 women. The respondents were surveyed twice in a 2-week interval. The repeatability of the questionnaire was verified by determining the Pearson correlation coefficient between the results obtained for the same people in the first and second interview, thus determining the intra-subject variability. Inter-subject variability was analysed by comparing the average values of physical activity for the whole group using the Student's $t$-test for dependent samples.

Results: For all levels of physical activity, a high correlation between the results obtained in both interviews was found. The correlation coefficient for total physical activity was $r=0.96$. The reproducibility of the results obtained from PPAQ questionnaire was the highest for inactivity and moderate activity $(r=0.96)$. The analysis according to the type of activity showed that the reproducibility was the highest for occupational activity $(r=0.98)$.

Conclusions: High reproducibility of results obtained using PPAQ questionnaire was found. This allows the assessed questionnaire to be considered as an accurate measurement tool that can be a source of reliable information about physical activity in pregnant women.
\end{abstract}

\section{Streszczenie}

Wprowadzenie: Wyniki wielu badań potwierdzają pozytywny wpływ aktywności fizycznej w czasie ciąży zarówno na zdrowie matki, jak i dziecka. Ze względu na znaczenie aktywności fizycznej dla zdrowia matki i dziecka istotne jest stosowanie ujednoliconych metod jej oceny.

Cel pracy: Walidacja kwestionariusza Pregnancy Physical Activity Questionnaire (PPAQ) poprzez określenie jego powtarzalności. Materiał i metody: Walidację kwestionariusza przeprowadzono w grupie 164 kobiet od czerwca 2014 do lutego 2015 r. Badanie respondentek wykonano dwukrotnie w dwutygodniowym odstępie czasu. Powtarzalność kwestionariusza sprawdzono poprzez wyznaczenie współczynnika korelacji Pearsona pomiędzy wynikami uzyskanymi dla tych samych osób w pierwszym i drugim wywiadzie, określając w ten sposób zmienność wewnątrzosobniczą. Zmienność międzyosobniczą analizowano poprzez porównanie średnich wartości aktywności fizycznej dla całej grupy za pomocą testu $t$-Studenta dla prób zależnych. Wyniki: Dla wszystkich poziomów aktywności fizycznej stwierdzono wysoką korelację pomiędzy wynikami uzyskanymi w obu wywiadach. Współczynnik korelacji dla całkowitej aktywności fizycznej wynosił $r=0,96$. Powtarzalność wyników uzyskanych z kwestionariusza PPAQ była najwyższa dla braku aktywności i umiarkowanej aktywności $(r=0,96)$. W analizie wg typu aktywności powtarzalność była najwyższa dla aktywności zawodowej $(r=0,98)$.

Wnioski: Stwierdzono wysoką powtarzalność wyników uzyskiwanych za pomocą kwestionariusza PPAQ. Kwestionariusz okazuje się trafnym narzędziem pomiarowym, które może być źródłem rzetelnych informacji o aktywności fizycznej kobiet w ciąży. 


\section{Introduction}

The results of many studies confirm the positive effect of physical activity during pregnancy on the health of both mother and child [1]. Increased physical activity in pregnant women in conjunction with a proper diet was connected with a lower risk of excessive weight gain in pregnancy, cesarean delivery, macrosomia, and neonatal respiratory morbidity [2], had a positive effect on the concentration of cholesterol, C-reactive protein (CRP), and blood pressure [3], and reduced the risk of preeclampsia [4] and gestational diabetes [5]. Regular exercise helped to maintain cardiovascular fitness levels throughout pregnancy, recovery of shape after childbirth [6], and improved sleep quality in pregnant women [7]. In case of miscarriage, women who were physically active reported significantly lower symptoms of depression compared to women who were not active [8]. Physical activity in combination with a proper diet during pregnancy also reduced the risk of overweight and obesity in women after childbirth [9] as well as the risk of overweight and obesity in the later years of the child's life [10].

Due to the significant impact of physical activity on the health of the mother and the child, it is important to use standardised methods of assessment, which give the opportunity to compare the results of studies conducted in different countries, to monitor trends in activity, and to assess the effectiveness of intervention programs. Methods for assessment of physical activity of a person can be divided into objective and subjective [11]. Objective methods using various types of motion sensors are preferred in the studies. Due to the high cost, they are not commonly used in cohort studies on a large scale. Increasingly used accelerometers also have their limitations. They are primarily associated with the inability to measure certain types of activities, e.g. water sports, cycling, and activities that first of all require movements of the upper parts of the body, as well as the inability to grasp the context of physical activity (e.g. walking while carrying a load or walking uphill). The main advantage of subjective methods is that they do not require complicated and expensive technical equipment, and they are not troublesome for the respondents, and therefore do not change their behaviour. They allow for a comprehensive assessment of the respondents' physical activity related to all aspects of their life.

In 2004, Chasan-Taber et al. developed the Pregnancy Physical Activity Questionnaire (PPAQ), taking into account household/caregiving activities, occupational activities, sports/exercise activities, transportation activities, and inactivity. The PPAQ measures the frequency and duration of activities and gives an intensity value to each activity. The PPAQ has been translated into many languages and is used to study the physical activity of pregnant women in different countries [12-16].

\section{Aim of the research}

The aim of this study was validation of the Polish version of the PPAQ by determination of its reproducibility.

\section{Material and methods}

\section{Organisation of studies and sampling}

The studies were conducted from June 2014 to February 2015 among pregnant women living in the Świętokrzyskie Voivodeship. The studied sample was selected using a snowball method from among women attending childbirth classes. A total of 176 women were recruited. From the basic set, the data of two women ( $1 \%$ of the respondents) were removed, which were considered to be unreliable in terms of weekly physical activity according to the algorithm developed by a team of experts - the authors of the PPAQ [17] (Figure 1). The collected data was then verified and cleaned by removing the respondents due to incomplete personal data, unreliable information, and thick errors (so-called "outliers"). In this way, the data of 12 respondents were removed ( $7 \%$ of the sample). Finally, the basic set of data included 164 women aged 18 to 42 years (mean age: $28.0 \pm 5.0$ years). During the first study, $17 \%$ of the women were in the first trimester, $56 \%$ in the second, and $27 \%$ in the third trimester of pregnancy. In the second study, conducted at intervals of two weeks after the first one, $6 \%$ women of the were in the first trimester, 58\% in the second, and $36 \%$ in the third trimester of pregnancy. The characteristics of the research group are presented in Table 1.

The studies were conducted with the consent of the Bioethics Committee at the Faculty of Health Science of Jan Kochanowski University.

\section{Characteristics of PPAQ questionnaire}

The PPAQ questionnaire contains questions concerning physical effort, which includes 32 types of physical activity. Its first part related to physical activity in the household and any other unpaid work that could be done outside the house. The second part of

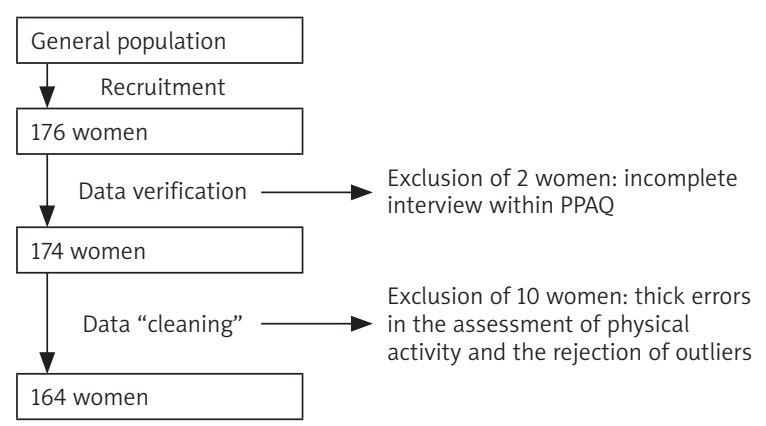

Figure 1. Diagram of sampling 
Table 1. Sample characteristic

\begin{tabular}{|lc|}
\hline Variables & Result \\
Sample number & 164 \\
Age* [years] & $28.0 \pm 5.0$ \\
BMI before pregnancy $\left[\mathrm{kg} / \mathrm{m}^{2}\right]$ & $21.3 \pm 2.5$ \\
Current month of pregnancy* & $5.2 \pm 1.7$ \\
\hline Trimester of pregnancy: & 17 \\
\hline I & 56 \\
\hline II & 27 \\
\hline III & 4 \\
\hline Education: & 19 \\
\hline Primary & 77 \\
\hline Secondary & 16 \\
\hline Higher & 41 \\
\hline Place of residence: & 21 \\
\hline Village & 38 \\
\hline Town $\leq 50,000$ residents & 19 \\
\hline City $>50,000$ residents & 16 \\
\hline Employment: & \\
\hline Intellectual work & \\
\hline Manual labour & \\
\hline Unemployed & 19 \\
\hline
\end{tabular}

Expressed as mean and standard deviation or percentage.

the questionnaire included questions about the physical effort associated with transportation from place to place, including work, shopping, entertainment, etc. Transportation could be done by car, bus, train, tram, bicycle, and walking. The third part of the questionnaire concerned certain types of physical effort associated with recreation, sport, exercise, and entertainment as well as active recreation or leisure. The fourth part concerned physical effort associated with occupational work and learning in different positions.

The original language version of the questionnaire was translated into Polish in accordance with the international recommendations for adaptation of tests and questionnaires [18]. The next step was testing the translated version of the questionnaire in order to assess the understanding of the questions and the accuracy of the wording. As a result of this process, the final version of the questionnaire was established. Responses to the questionnaire ranged from 0 to 6 or more hours during the day or from 0 to $3 \mathrm{~h}$ during the week. A section of open questions appended at the end of the PPAQ allowed the respondents to add ac- tivities not listed in the questionnaire. Sleep time was not taken into account. The time spent for each physical activity included in the PPAQ reported by women was multiplied by its intensity, and as a result, for each of the activities, the associated average weekly energy expenditure (MET-h/week) was obtained. The METs values given in the Compendium of Physical Activity [19] were used to estimate the intensity of the other forms of activity included in the PPAQ. Activities with lower or higher intensity were summed up to obtain an average value of the total activity expressed in METs per hour during the week. Each activity was classified according to intensity into: sedentary (1.5 METs), light (1.5-3.0 METs), moderate (3.0-6.0 METs), or high (> 6.0 METs). Furthermore, for each of the aforementioned levels of activity, the average number of METs per hour during the week was calculated. Activities were also classified according to their type (household/caregiving activities, occupational activities, sports and exercise activities, transportation), giving the average number of METs per hour during the week spent on each type.

Validation of the method for assessing physical activity by determining its reproducibility consists of comparison of the results of the assessment of the activity obtained using a validated method with the results obtained using the same method, which was repeated (comparison: "test-retest"), assuming that the test and retest measurement conditions were the same.

\section{Statistical analysis}

Statistical analysis was performed using the statistical package Statistica PL v. 10.0 from StatSoft. Compliance of the schedule of the studied characteristics with the normal schedule was checked using the Kolmogorov-Smirnov test. The values of the characteristics were expressed as average value $(x)$ and their volatility in the standard deviation (SD) and the minimum value (min.) and the maximum value (max.). The repeatability of the questionnaire was verified by determining the Pearson correlation coefficient $(r)$ between the results obtained for the same people in the first and second interview, thus determining the intra-subject variability. Intra-subject variability was analysed by comparing the average values of physical activity for the whole group using the Student's $t$-test (T) for dependent samples.

\section{Results}

The questionnaire's reproducibility was assessed in a group of 164 pregnant women. The median of physical activity in the first PPAQ interview was 113.9 MET h/week, while in the second interview it was slightly lower at 112.4 MET h/week (Table 2). No women in the first or second interview declared high physical activity (> 6.0 METs). The most com- 
Table 2. Comparison of two self-administered Pregnancy Physical Activity Questionnaires (PPAQs) by activity intensity and type among 164 pregnant subjects

\begin{tabular}{|c|c|c|c|c|c|c|}
\hline \multirow[t]{2}{*}{ Variables } & \multicolumn{3}{|c|}{$\begin{array}{c}1^{\text {st }} \text { PPAQ } \\
{[M E T \text { h/week] }}\end{array}$} & \multicolumn{3}{|c|}{$\begin{array}{c}2^{\text {nd }} \text { PPAQ } \\
{[M E T \text { h/week] }}\end{array}$} \\
\hline & $X \pm \mathrm{SD}$ & Min. & Max. & $X \pm \mathrm{SD}$ & Min. & Max. \\
\hline Sample size & & 164 & & & 164 & \\
\hline Total activity (light and above) & $126.0 \pm 81.5$ & 0.0 & 655.3 & $122.1 \pm 81.8$ & 0.0 & 154.6 \\
\hline \multicolumn{7}{|l|}{ By intensity: } \\
\hline Sedentary (1.5 METs) & $60.7 \pm 41.2$ & 0.0 & 176.1 & $59.7 \pm 40.8$ & 0.0 & 95.5 \\
\hline Light (1.5-<3.0 METs) & $44.1 \pm 35.9$ & 0.0 & 167.2 & $41.7 \pm 35.9$ & 0.0 & 53.6 \\
\hline Moderate activity (3.0-6.0 METs) & $20.4 \pm 42.1$ & 0.0 & 440.5 & $19.9 \pm 42.5$ & 0.0 & 10.5 \\
\hline Vigorous activity (> 6.0 METs) & $0.8 \pm 2.0$ & 0.0 & 12.0 & $0.8 \pm 2.0$ & 0.0 & 0.0 \\
\hline \multicolumn{7}{|l|}{ By type: } \\
\hline Household/caregiving & $72.7 \pm 49.0$ & 0.0 & 248.0 & $69.7 \pm 47.9$ & 0.0 & 262.6 \\
\hline Occupational activity & $37.0 \pm 61.5$ & 0.0 & 592.2 & $36.7 \pm 61.3$ & 0.0 & 592.2 \\
\hline Sports/exercise & $6.8 \pm 7.1$ & 0.0 & 39.4 & $6.4 \pm 7.1$ & 0.0 & 42.0 \\
\hline Transportation & $9.5 \pm 14.8$ & 0.0 & 105.0 & $9.2 \pm 14.8$ & 0.0 & 105.0 \\
\hline
\end{tabular}

Table 3. Comparison of two self-administered Pregnancy Physical Activity Questionnaires (PPAQs) by activity intensity and type among 164 pregnant subjects; PPAQ validation phase (MET h/week; mean \pm standard deviation)

\begin{tabular}{|c|c|c|c|c|}
\hline Variables & $\begin{array}{c}1^{\text {st }} \text { PPAQ } \\
{[\text { MET h/week] }}\end{array}$ & $\begin{array}{c}2^{\text {nd }} \text { PPAQ } \\
{[M E T \text { h/week] }}\end{array}$ & $P$-value & $\begin{array}{c}\text { Intraclass } \\
\text { correlation } \\
\text { coefficient }(r)\end{array}$ \\
\hline Sample size & 164 & 164 & & \\
\hline Total activity (light and above) & $126.0 \pm 81.5$ & $122.1 \pm 81.8$ & NS & $0.96^{*}$ \\
\hline \multicolumn{5}{|l|}{ By intensity: } \\
\hline Sedentary (1.5 METs) & $60.7 \pm 41.2$ & $59.7 \pm 40.8$ & NS & $0.96^{*}$ \\
\hline Light (1.5-<3.0 METs) & $44.1 \pm 35.9$ & $41.7 \pm 35.9$ & NS & $0.93^{\star}$ \\
\hline Moderate activity (3.0-6.0 METs) & $20.4 \pm 42.1$ & $19.9 \pm 42.5$ & NS & $0.96^{*}$ \\
\hline Vigorous activity (> 6.0 METs) & $0.8 \pm 2.0$ & $0.8 \pm 2.0$ & NS & $0.72^{\star}$ \\
\hline \multicolumn{5}{|l|}{ By type: } \\
\hline Household/caregiving & $72.7 \pm 49.0$ & $69.7 \pm 47.9$ & NS & $0.92^{\star}$ \\
\hline Occupational activity & $37.0 \pm 61.5$ & $36.7 \pm 61.3$ & NS & $0.98^{*}$ \\
\hline Sports/exercise & $6.8 \pm 7.1$ & $6.4 \pm 7.1$ & NS & $0.89^{*}$ \\
\hline Transportation & $9.5 \pm 14.8$ & $9.2 \pm 14.8$ & NS & $0.92^{\star}$ \\
\hline
\end{tabular}

$P$-value - level of significance o T-test, NS - non-significant; *level of significance of correlation coefficient $(p<0.001)$.

mon type of activity was light activity (1.5-3.0 METs). The respondents, both in the first and in the second interview, showed the highest activity in domains of household/caregiving. Comparison of the results obtained in the first and second study did not show significant differences in physical activity, with regard to any different level of intensity of physical activity
(Table 3). For all levels of intensity, a high correlation between the results obtained in both interviews was found. The correlation coefficient for total physical activity was $r=0.96$. The reproducibility of the results obtained from PPAQ questionnaire was the highest for inactivity, while the lowest was in the case of highintensity activity $(r=0.72)$. In the analysis conducted 
according to the type of activity, the reproducibility was highest for occupational activity $(r=0.98)$ and lowest for sports/exercise $(r=0.89)$.

\section{Discussion}

The analysis showed no significant differences between the results of both studies, which indicates a low intra-subject variability and high reproducibility of the obtained results. The studies of repeatability and accuracy of the PPAQ conducted by the authors of the questionnaire showed that the intra-class correlation coefficients used to measure reproducibility of the PPAQ were 0.78 for total activity, 0.82 for moderate activity, 0.81 for vigorous activity, and ranged from 0.83 for sports/exercise to 0.93 for occupational activity [17]. Spearman correlations between the PPAQ and three published cutoff points used to classify actigraph data ranged from 0.08 to 0.43 for total activity, 0.25 to 0.34 for vigorous activity, 0.20 to 0.49 for moderate activity, and 0.08 to 0.22 for light-intensity activity. The high usefulness of the questionnaire for the assessment of physical activity of pregnant women has been confirmed in studies using it in many other countries [12-15, 20, 21]. Validation of PPAQ conducted by Chinese researchers demonstrated a very high reproducibility of 0.944 , while the correlation coefficient between the results obtained on the basis of the questionnaire and the results of activity measurement using pedometer was $r=0.768[14,15]$, which showed that the PPAQ also allows for a reliable assessment of the activity of pregnant women with obesity and can be used in the assessment of adherence to the recommendations for physical activity during pregnancy as well as in the studies aimed at analysing the effectiveness of various intervention programs. Correlation between data obtained from the PPAQ and data from the measurement of activity using an accelerometer confirmed a moderate but acceptable accuracy of the questionnaire in a group of obese pregnant women.

This study, however, was subject to several limitations. Occupational activity and household/caregiving activities are quite similar in different seasons; however, sports/exercise activities may exhibit seasonal differences. Although each woman was studied in one season, the studies were conducted in the period from June to February. Moreover, the studied group was not representative of the general population. The analysis, however, confirmed the high reproducibility of results obtained using the questionnaire assessed. In the authors' opinion, the PPAQ can be used to determine the lower and upper levels of rigor (intensity, duration, frequency) for activity during pregnancy, and to identify the specific parameters that characterise both threshold and dose response effects for investigations of physical activity and foetal and maternal outcomes [17]. The usefulness of the questionnaire for the assessment of physical activity in pregnant women should be emphasised especially in relation to the great need for further studies on the impact of physical activity and sedentary behaviour of pregnant women on the risk of adverse health effects for infants and mothers in their later life [1].

\section{Conclusions}

High reproducibility of results obtained using PPAQ questionnaire was found. This allows the assessed questionnaire to be considered as an accurate measurement tool that can be a source of reliable information about physical activity in pregnant women.

\section{Conflict of interest}

The authors declare no conflict of interest.

\section{References}

1. Downs DS, Chasan-Taber L, Evenson KR, Leiferman J, Yeo S. Physical activity and pregnancy: past and present evidence and future recommendations. Res Q Exerc Sport 2012; 83: 485-502.

2. Muktabhant B, Lawrie TA, Lumbiganon P, Laopaiboon M. Diet or exercise, or both, for preventing excessive weight gain in pregnancy. Cochrane Database Syst Rev 2015; 6: CD007145.

3. Loprinzi PD, Fitzgerald EM, Woekel E, Cardinal BJ. Association of physical activity and sedentary behavior with biological markers among U.S. pregnant women. J Womens Health 2013; 22: 953-8.

4. Pivarnik JM, Chambliss H, Clapp J. Impact of physical activity during pregnancy and postpartum on chronic disease risk. Med Sci Sports Exerc 2006; 38: 989-1006.

5. Colberg SR, Castorino K, Jovanović L. Prescribing physical activity to prevent and manage gestational diabetes. World J Diabetes 2013; 4: 256-62.

6. Davies G, Wolfe L, Mottola M, MacKinnon C. Joint SOGC/ CSEP clinical practice guideline: exercise in pregnancy and the postpartum period. Can J Appl Physiol 2003; 28: 330-41.

7. Loprinzi PD, Loprinzi KL, Cardinal BJ. The relationship between physical activity and sleep among pregnant women. Ment Health Phys Act 2012; 5: 22-7.

8. Huberty J, Leiferman JA, Gold KJ, Rowedder L, Cacciatore J, McClain DB. Physical activity and depressive symptoms after stillbrith: informing future interventions. BMC Pregnancy Childbirth 2014; 14: 391.

9. Phelan S, Phipps MG, Abrams B, Darroch F, Grantham K, Schaffner A. Does behavioral intervention in pregnancy reduce postpartum weight retention? Twelve-month outcomes of the Fit for Delivery randomized trial. Am J Clin Nutr 2014; 99: 302-11.

10. Mourtakos SP, Tambalis KD, Panagiotakos DB, Antonogeorgos G, Arnaoutis G, Karteroliotis K, Sidossis LS. Maternal lifestyle characteristics during pregnancy, and the risk of obesity in the offspring: a study of 5,125 children. BMC Pregnancy Childbirth 2015; 15: 66.

11. Lipert A, Jegier A. Metody pomiaru aktywności ruchowej. Medycyna Sportowa Medsportpress 2009; 25: 155-68.

12. Ota E, Haruna M, Yanai H, Suzuki M, Matsuzaki M, Ariyoshi K, Yeo S, Murashima S. Reliability and validity of the 
Vietnamese version of the pregnancy physical activity questionaire (PPAQ). Southeast Asian J Trop Med Public Health 2008; 39: 562-70.

13. Matsuzaki M, Haruna M, Ota E, Seon Ae Yeo, Murayama R, Murashima S. Translation and cross-cultural adaptation of the Pregnancy Physical Activity Questionnaire (PPAQ) to Japanese. BioScience Trends 2010; 4: 170-7.

14. Chandonnet N, Saey D, Almeras N, Marc I. French pregnancy physical activity questionnaire compared with an accelerometer cut point to classify physical activity among pregnant obese women. PLoS One 2012; 7: e38818.

15. Zhang Y, Zhao Y, Dong SW, Xiong Y, Xq H. Reliability and validity of the Chinese version of the Pregnancy Physical Activity Questionnaire (PPAQ). Chin J Nurs 2013; 48: 825-7.

16. Cirak Y, Yilmaz GD, Demir YP, Dalkilnc M, Yaman S. Pregnancy physical activity questionnaire (PPAQ): reliability and validity of Turkish version. J Phys Therapy Sci 2015; 27: 3703-9.

17. Chasan-Taber L, Schmidt MD, Roberts DE, Hosmer D, Markenso G, Federson PS. Development and validation of a Pregnancy Physical Activity Questionnaire. Med Sci Sports Exerc 2004; 36: 1750-60.

18. Szkultecka-Dębek M, Bem M, Mazur J. Różnice kulturowe - wpływ na ocenę jakości życia związanej ze zdrowiem. Farmakoekonomika 2006; 10: 3-10.

19. Ainsworth BE, Haskell WL, Herrmann SD, Meckes N, Bassett DR Jr, Tudor-Locke C, Greer JL, Vezina J, Whitt-Glover MC, Leon AS. Compendium of physical activities: a second update of codes and MET values. Med Sci Sports Exerc 2011; 43: 1575-81.

20. Zhang Y, Dong S, Zuo J, Hu X, Zhang H. Physical activity level of urban pregnant women in Tianjin, China: a crosssectional study. PLoS One 2014; 9: e109624.

21. Hawkins M, Braun B, Marcus BH, Stanek E, Markenson G, Chasan-Taber L. The impact of an exercise intervention on C-reactive protein during pregnancy: a randomized controlled trial. BMC Pregnancy Childbirth 2015; 15: 139.

\section{Address for correspondence:}

\section{Grzegorz Król}

Department of the Prevention of Alimentary

Tract Diseases

Institute of Nursing and Obstetrics

Faculty of Medicine and Health Science

Jan Kochanowski University

al. IX Wieków Kielc 19, 25-317 Kielce, Poland

Phone: +48510447 299

E-mail: g.krol@op.pl 